\title{
MENENTUKAN LINTASAN TERPENDEK (SHORTEST PATH) DENGAN 0/1 KNAPSACK PROBLEM DAN PENDEKATAN ALGORITMA DYNAMIC PROGRAMMING
}

\author{
Iwan Fitrianto $\mathrm{R}^{1}$ \\ Djoko Soetarno ${ }^{2}$ \\ e-mail:iwanfitrianto@yahoo.com,djokosoetarno@yahoo.com.
}

Diterima : 29 Maret 2011 / Disetujui : 12 April 2011

\begin{abstract}
Knapsack is one of the classic problems that are found in everyday life. Knapsack can be interpreted as a sack or bag. Sacks used to load anything and certainly not all objects can be accommodated inside the sack. Sacks can only store a few objects with total size less than or equal to the size of the sack capacity. In principle, the Knapsack problem is the optimization problem so that the algorithm must find an optimal solution as the answer. This paper will discuss how to solve the $0 / 1$ Knapsack Problem using Dynamic Programming algorithm approach
\end{abstract}

Keywords: Knapsack, Dynamic Programming Algorithms.

\section{ABSTRAKSI}

Knapsack merupakan salah satu permasalahan klasik yang banyak ditemukan di kehidupan sehari-hari. Knapsack dapat diartikan sebagai karung atau kantung. Karung digunakan untuk memuat sesuatu dan tentunya tidak semua objek dapat ditampung di dalam karung. Karung tersebut hanya dapat menyimpan beberapa objek dengan total ukurannya lebih kecil atau sama dengan ukuran kapasitas karung. Pada prinsipnya masalah Knapsack ini adalah masalah optimalisasi sehingga algoritma harus mencari sebuah solusi paling optimal sebagai jawabannya. Tulisan ini akan membahas bagaimana menyelesaikan 0/1 Knapsack Problem dengan menggunakan pendekatan Algortima Dynamic Programming.

Kata Kunci : Knapsack, Algoritma Dynamic Programming.

1. Dosen Jurusan Teknik Informatika, STMIK Potensi Utama

J1. K.L. Yos Sudarso Km. 6,5 No. 3 A Tj. Mulia, Medan, Telp (061) 6640525

2. Dosen Jurusan Sistem Komputer, STMIK Raharja

Jl. jend Sudirman No. 40 Modern Cikokol-Tangerang Telp. 5529692 


\section{PENDAHULUAN}

Knapsack merupakan salah satu permasalahan klasik yang banyak ditemukan di kehidupan sehari-hari. Knapsack dapat diartikan sebagai karung atau kantung. Karung digunakan untuk memuat sesuatu dan tentunya tidak semua objek dapat ditampung di dalam karung. Karung tersebut hanya dapat menyimpan beberapa objek dengan total ukurannya lebih kecil atau sama dengan ukuran kapasitas karung.

Contoh permasalahan ini seperti penjualan beberapa jenis peralatan rumah tangga oleh pedagang keliling dengan menggunakan gerobak ataupun alat pengangkut lainnya. Keperluan rumah tangga yang akan dijual hanya berjumlah satu untuk tiap jenisnya dan tiap jenis barang memiliki berat dan keuntungan. Tidak semua jenis keperluan rumah tangga yang akan dijual oleh pedagang keliling tersebut dapat dimasukkan ke dalam alat pengangkut. Tentu saja dikarenakan alat pengangkutnya memiliki kapasitas maksimum sehingga si pedagang tidak bisa memasukkan seluruh dagangannya. Pedagang tersebut harus memilih barang-barang mana saja yang harus ia angkut dengan pertimbangan berat dari barang yang dibawanya tidak melebihi kapasitas maksimum gerobak dan memaksimalkan keuntungan dari barang-barang yang ia bawa.

Terdapat beberapa variasi Knapsack Problem:

1. Fractional Knapsack Problem Barang boleh dibawa sebagian saja (unit dalam pecahan).

2. $0 / 1$ Knapsack Problem Setiap barang hanya tersedia satu unit, diambil atau tinggalkan.

3. Bounded Knapsack Problem Setiap barang tersedia sebanyak N unit (jumlah barang terbatas).

4. Unbounded Knapsack Problem Setiap barang tersedia lebih dari satu unit, jumlahnya tidak terbatas [7].

Pada prinsipnya masalah Knapsack ini adalah masalah optimalisasi sehingga algoritma harus mencari sebuah solusi paling optimal sebagai jawabannya.

Permasalahan Combinatorial Optimizationn dikenal sebagai NP Hard Problem. Masalah Knapsack tidak dapat diselesaikan dalam waktu singkat hanya dapat diselesaikan dengan waktu yang lama disebabkan karena banyak data yang digunakan sebagai data input. Semakin besar data yang digunakan, maka waktu yang dibutuhkan suatu algoritma untuk menyelesaikan juga semakin lama. 
Banyak algoritma yang dapat digunakan untuk menyelesaikan Knapsack Problem ini, misalnya Algoritma Brute Force, Branch and Bound, Greedy, Genetika dan lain-lain. Dalam tulisan ini, membahas Knapsack Problem dengan menggunakan Algoritma Dynamic proramming.

\section{HASIL DAN PEMBAHASAN}

\section{Konsep Dasar Graph}

Sebelum sampai pada penDefinisian masalah lintasan terpendek, terlebih dahulu pada bagian ini akan diuraikan mengenai konsep-konsep dasar dari model graph dan representasinya dalam memodelkan masalah lintasan terpendek.

Definisi: Sebuah graph $G$ terdiri dari himpunan $V=V(G)$ yang memiliki elemenelemen yang disebut verteks, dan kumpulan $\mathrm{E}=\mathrm{E}(\mathrm{G})$ yang merupakan pasangan tak berurut dari verteks yang berbeda yang disebut edge.

Secara umum graph dapat digambarkan dengan suatu diagram dimana verteks ditunjukkan sebagai titik yang dinotasikan dengan $\mathrm{v}_{\mathrm{i}}, \mathrm{i}=1,2, \ldots, \mathrm{P}$ dan edge digambarkan dengan sebuah garis lurus atau garis lengkung yang menghubungkan dua verteks $\left(\mathrm{v}_{\mathrm{i}} \mathrm{v}_{\mathrm{j}}\right)$ dan dinotasikan dengan $\mathrm{e}_{\mathrm{k}}$. sebagai ilustrasi dapat dilihat gambar 2.1. yaitu suatu graph yang mempunyai lima verteks dan enam edge.

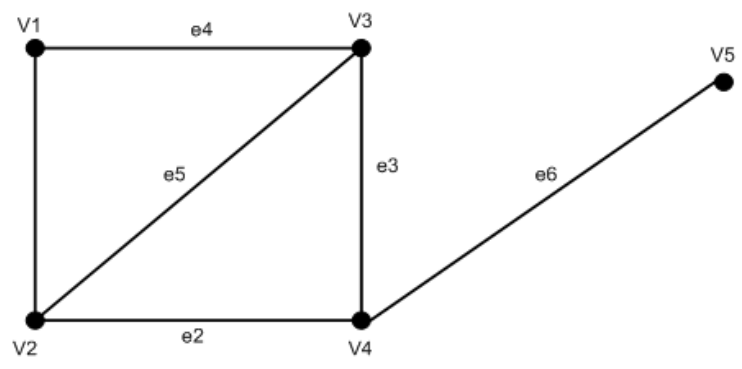

Gambar 2.1. Graph 5 Verteks dan 6 Edge

Definisi : suatu digraph $G$ terdiri dari himpunan verteks-verteks $V(G):\left\{v_{1}, v_{2}\right.$, $\ldots\}$, himpinan edge-edge $\mathrm{E}(\mathrm{G}):\left\{\mathrm{e}_{1}, \mathrm{e}_{2}, \ldots\right\}$, dan suatu fungsi $\Psi$ yang mngawankan setiap edge dalam $E(G)$ ke suatu pasangan berurutan verteks $\left(v_{i}, v_{j}\right)$.

Jika $e_{k}=\left(v_{i}, v_{j}\right)$ adalah suatu edge dalam $G$, maka $v_{i}$ disebut verteks awal $e_{k}$ dan $v_{j}$ disebut verteks akhir $\mathrm{e}_{\mathrm{k}}$. Arah edge adalah dari $\mathrm{v}_{\mathrm{i}} \mathrm{ke}_{\mathrm{j}}$.

Perhatikan digraph $\mathrm{G}$ pada gambar 2.2. dibawah ini. 


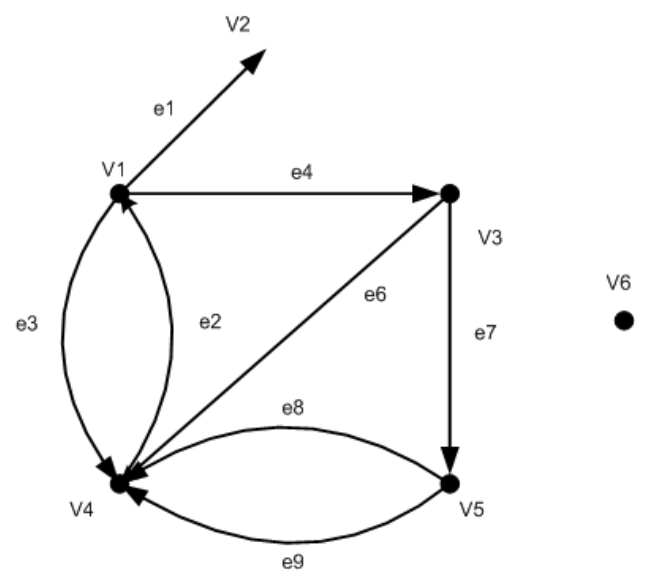

Gambar 2.2. Digraph $G$

Jika $G$ adalah graph (berarah atau tidak) dengan verteks $\mathrm{V}$ dan edge $\mathrm{E}$, maka dapat ditulis $\mathrm{G}=(\mathrm{V}, \mathrm{E})$.

\section{Graph Berlabel}

Hubungan antar verteks-verteks dalam graph perlu diperjelas. Hubungan tidak cukup hanya menunjukkan verteks-verteks mana yang berhubungan langsung, tetapi juga seberapa kuat hubungan itu. Verteks- verteks graph menyatakan kota-kota yang ada di daerah tersebut. Edge-edge dalam graph menyatakan jalan yang menghubungkan kota-kota tersebut.

Informasi tentang peta daerah perlu diperjelas dengan mencantumkan jarak antara 2 kota yang berhubungan. Informasi tentang jarak dibutuhkan karena dalam graph, letak verteks dan panjang edgenya tidak menyatakan jarak 2 kota yang sebenarnya. Jadi setiap garis dalam graph berhubungan dengan suatu label yang menyatakan bobot garis tersebut.

Definisi: Graph Berlabel (weighted graph) adalah suatu graph tanpa edge paralel dimana setiap edgenya berhubungan dengan suatu bilangan riil tak negatif yang menyatakan nilai edge (w(e)) tersebut. Jumlah nilai semua edge disebut Total Nilai.

Matriks yang bersesuaian dengan graph berlabel $\mathrm{G}$ adalah adjacency matriks $\mathrm{A}=\left(\mathrm{a}_{\mathrm{ij}}\right)$ dengan $\mathrm{a}_{\mathrm{ij}}=$ nilai edge yang menghubungkan verteks $\mathrm{v}_{\mathrm{i}}$ maka $_{\mathrm{ij}}=\infty$, dan $\mathrm{a}_{\mathrm{ij}}=0$ jika $\mathrm{I}=\mathrm{j}$.

Contoh. Dalam suatu propinsi, ada $8 \operatorname{kota}\left(\mathrm{v}_{1}, \mathrm{v}_{2}, \ldots, \mathrm{v}_{8}\right)$ yang akan dihubungkan dengan jaringan listrik. Biaya pemasangan jaringan listrik yang mungkin dibuat antar 2 kota sebagai berikut: 


\begin{tabular}{|c|c|c|}
\hline Edge & Kota yang dihubungkan & Biaya per satuan \\
\hline e4 & v2 - v3 & 3 \\
\hline e7 & $\mathrm{v} 4$ - v6 & 4 \\
\hline e2 & $\mathrm{v} 1-\mathrm{v} 7$ & 5 \\
\hline e8 & $v 3-v 4$ & 5 \\
\hline e9 & v3 -v5 & 5 \\
\hline e1 & $\mathrm{v} 1-\mathrm{v} 2$ & 15 \\
\hline e3 & $\mathrm{v} 1-\mathrm{v} 4$ & 15 \\
\hline $\mathrm{e} 10$ & $\mathrm{v} 6$-v8 & 15 \\
\hline e5 & v7 -v8 & 15 \\
\hline e11 & v5 -v6 & 15 \\
\hline e6 & v6 -v7 & 18 \\
\hline
\end{tabular}

a. Graph berlabel untuk menyatakan jaringan listrik di 8 kota dapat digambarkan pada gambar 2.3. dibawah ini. Angka dalam kurung menyatakan nilai edge yang bersangkutan. Nilai tersebut menyatakan biaya pengadaan jaringan listrik.

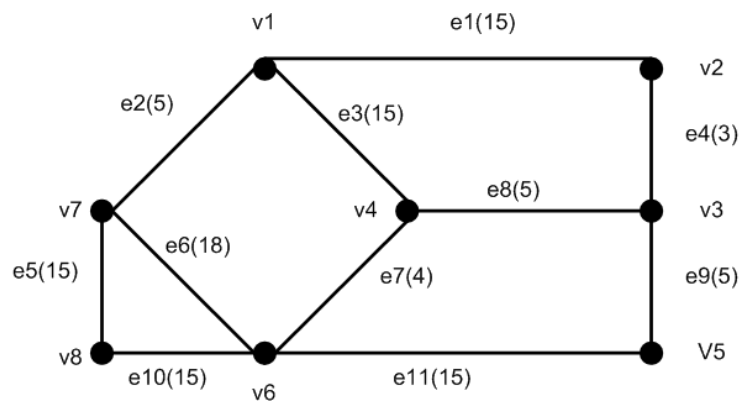

Gambar 2.3. Graph Jaringan Listrik 8 Kota

b. Adjacency Matriks untuk menyatakan graph berlabel pada gambar 2.3. adalah matriks $\mathrm{A}=\left(\mathrm{a}_{\mathrm{ij}}\right)$ dengan $\mathrm{a}_{\mathrm{ij}}=$

Jarak verteks $v_{i}$ dengan $v_{j} \quad$ jika ada edge yang menghubungkan verteks vdengan $\mathrm{v}_{\mathrm{j}}$

$\infty \quad$ jika tidak ada edge yang menghubungkan verteks $v_{i}$ dengan $v_{j}$

$0 \quad$ jika $\mathrm{i}=\mathrm{j}$

Misalkan $\mathrm{G}$ adalah sebuah graph berarah. Sebuah edge berarah $\mathrm{e}=[u, \underline{\mathrm{v}}]$ dikatakan mulai pada verteks awal $u$ dan berakhir di verteks akhir $v, u$ dan $v$ dikatakan adjacent.

Definisi : Derajat luar dari v, (outdeg (v)) adalah jumlah edge yang berawal pada v, dan derajat $\mathrm{v}$ (indeg (v)) adalah jumlah edge yang berakhir di $\mathrm{v}$. 
Karena setiap edge mulai dan berakhir pada suatu verteks maka jumlah derajatdalam dan jumlah derajat-luar harus sama dengan n, yaitu jumlah edge pada $\mathrm{G}$.

Definisi : Sebuah verteks v di G disebut sumber (source) jika ia mempunyai derajatluar positif tetapi derajat-dalam nol. Sedangkan, v disebut tujuan (sink) jika v mempunyai derajat-dalam positif tetapi derajat-luar nol.

Perhatikan gambar 2.4, dibawah ini.

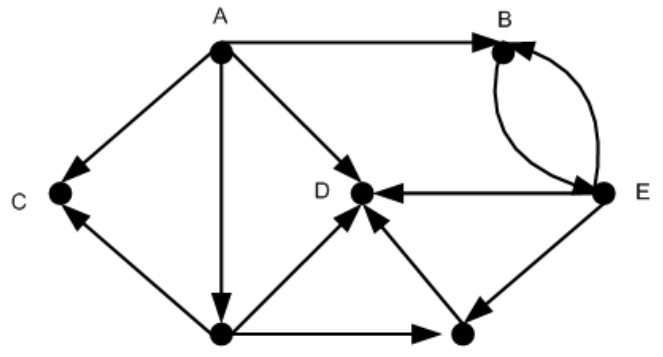

Gambar 2.4. Graph $G$ dengan 7 verteks

Gambar 2.4. diatas terdiri dari :

Verteks

Derajat-dalam (indegree)

A $\quad$ B

$0 \quad 2$

Derajat-luar (outdegree)

$4 \quad 1$

$\begin{array}{lllll}\text { C } & \text { D } & \text { E } & \text { F } & \text { G } \\ 2 & 4 & 1 & 1 & 2 \\ 0 & 0 & 3 & 3 & 1\end{array}$

Jumlah derajat dalam dan jumlah derajat luar dengan 12 yaitu jumlah busur.

Pada gambar 2.4. verteks A adalah sumber (source) karena edgenya berawal pada A tetapi tidak berakhir di A. Sedangkan C dan D adalah verteks tujuan (sink) karena edgenya berakhir di C dan D tetapi tidak berawal di verteks itu.

\section{Path Minimum}

Salah satu aplikasi graph berarah berlabel yang sering dipakai adalah mencari path terpendek diantara 2 verteks. Apabila masalahnya adalah mencari jalur terpendek tetap dapat digunakan dengan cara mengganti nilai edge.

Definisi : misalkan G adalah suatu graph, dimana v dan w adalah verteks dalam G. suatu Walk dari v ke w adalah barisan verteks - verteks berhubungan dan edge secara berselang-seling, diawali dari verteks $\mathrm{v}$ dan diakhiri pada verteks $\mathrm{w}$. walk dengan panjang $\mathrm{n}$ dari $\mathrm{v}$ ke $\mathrm{w}$ ditulis $: \mathrm{v}_{0} \mathrm{e}_{1} \mathrm{v}_{1} \mathrm{e}_{2} \mathrm{v}_{2} \ldots \mathrm{v}_{\mathrm{n}-2} \mathrm{e}_{\mathrm{n}} \mathrm{v}_{\mathrm{n}}$ dengn $\mathrm{v}_{0}=\mathrm{v}: \mathrm{v}_{\mathrm{n}}=\mathrm{w}$; $\mathrm{v}_{\mathrm{i}-1}$ dan $\mathrm{v}_{\mathrm{i}}$ adalah verteks-verteks ujung edge $\mathrm{e}_{\mathrm{i}}$.

Path dengan panjang $\mathrm{n}$ dari $\mathrm{v}$ ke $\mathrm{w}$ adalah walk dari $\mathrm{v}$ ke $\mathrm{w}$ yang semua edgenya berbeda. Path dari $\mathrm{v}$ ke $\mathrm{w}$ dituliskan sebagai $\mathrm{v}=\mathrm{v}_{0} \mathrm{e}_{1} \mathrm{v}_{1} \mathrm{e}_{2} \mathrm{v}_{2} \ldots \mathrm{v}_{\mathrm{n}-1} \mathrm{e}_{\mathrm{n}} \mathrm{v}_{\mathrm{n}}=\mathrm{w}$ dengan $e_{i} \neq e_{j}$ untuk $i \neq j$. 
Definisi : Lintasan adalah suatu barisan edge $\left(e_{i_{1}}, e_{i_{2}}, \ldots \ldots ., e_{i_{k}}\right)$ sedemikian rupa sehingga verteks terminal $e_{i_{j}}$ berimpit dengan verteks awal $e_{i_{(j+1)}}$ untuk $1 \leq j \leq k-1$.

\section{Contoh 2.2.}

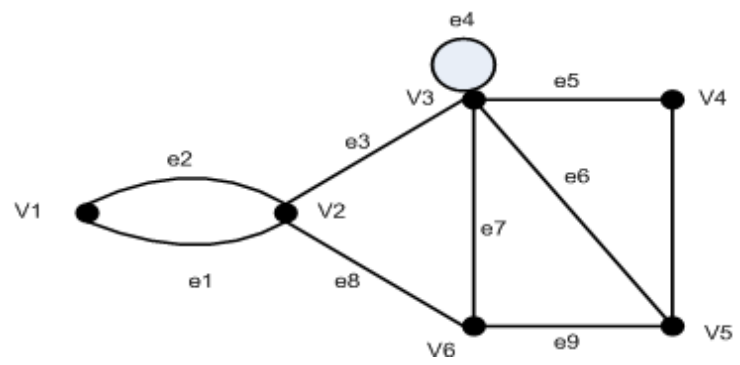

Gambar 2.5. Graph dengan 6 verteks dan 10 edge

Pada gambar 2.5. diatas terdapat:

a. Pada titik $v_{1} e_{1} v_{2} e_{3} v_{3} e_{4} v_{3} e_{5} v_{4}$ semua edge berbeda $\left(e_{1}, e_{3}, e_{4}\right.$, dan $e_{5}$ masing-masing muncul sekali). Ada verteks yang berulang ( $v_{3}$ muncul 2 kali ). Verteks awal dan verteks akhir tidak sama verteks awal $=v_{1}$ dan verteks akhir $=v_{4}$, Barisan ini merupakan Path dari $v_{1}$ ke $v_{4}$ dengan panjang 4.

b. Pada titik $v_{1} e_{1} v_{2} e_{3} v_{3} e_{5} v_{4} e_{5} v_{3} e_{6} v_{5}$ ada edge yang muncul lebih dari sekali, yaitu $e_{5}$ (muncul 2 kali) berarti barisan tersebut merupakan walk dari $v_{1}$ ke $v_{5}$ dengan panjang 5 .

\section{Shortest Path}

Setiap path dalam digraph mempuanyai nilai yang dihubungkan dengan nilai path tersebut, yang nilainya adalah jumlah dari nilai edge path tersebut.dari ukuran dasar ini dapat dirumuskan masalah seperti "mencari lintasan terpendek antara dua verteks dan meminimumkan biaya.

Banyak bidang penerapan mensyaratkan untuk menentukan lintasan terpendek berarah dari asal ke tujuan di dalam suatu distribusi aliran berarah. Algoritma yang diberikan dapat dimodifikasi dengan mudah untuk mrnghadapi lintasan berarah pada setiap iterasinya. 
Suatu versi yang lebih umum dari masalah lintasan terpendek adalah menentukan lintasan terpendek dari sembarang verteks menuju ke setiap verteks lainnya. Pilihan lainnya adalah membuang kendala tak negatif bagi "jarak". Suatu kendala lain dapat juga diberlakukan dalam suatu masalah lintasan terpendek.

Definisi : lintasan terpendek antara dua verteks dari s ke $t$ dalam jaringan adalah lintasan graph berarah sederhana dari s ke $t$ dengan sifat dimana tidak ada lintasan lain yang memiliki nilai terendah.

\section{Contoh 2.3.}

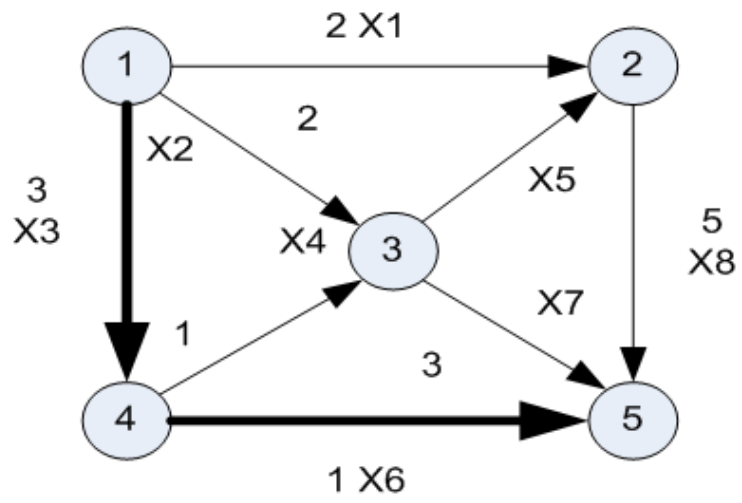

Gambar 2.6. Shortest path (garis tebal)

Pada gambar 2.6 dapat dilihat bahwa setiap edge terletak pada path-path dari titik 1 ke titik 5. Edge merepresentasikan saluran dengan kapasitas tertentu (contohnya, air) dapat dialirkan melalui saluran. Sedangkan verteks merepresentasikan persimpangan saluran. Air mengalir melalui verteks pada verteks yang dillalui Lintasan terpendek dari verteks pada graph diatas adalah $\mathrm{P}=\{1-4,4$ -5 \} dengan kapasitas 4.

\section{Linear Programming}

Program (linier) bilangan cacah adalah suatu bentuk dari program matematika. Ini adalah suatu kasus khusus dari program linier dimana semua (atau beberapa) variabel dibatasi sebagai bilangan cacah tak negatif. Kalau semua variabel dibatasi sebagai bilangan cacah, persoalannya disebut persoalan program bilangan cacah murni, dan kalau beberapa variabel tertentu dibatasi sebagai bilangan cacah campuran. Suatu bentuk khusus dari program bilangan cacah ialah suatu kasus dimana variabel dibatasi harus berharga nol atau satu. Kalau variabel dibatasi seperti ini, maka persoalannya disebut persoalan program nol-satu (0-1). 
Perumusan program linear dapat membantu prosedur penyelesaian lebih efisien. Berikut ini adalah bentuk umum program linear.

Minimumkan $c_{1} x_{1}+c_{2} x_{2}+\ldots+c_{n} x_{n}$

Dengan kendala

$$
\begin{aligned}
& a_{11} x_{1}+a_{12} x_{2}+\ldots+a_{1 n} x_{n}=b_{1} \\
& a_{12} x_{1}+a_{22} x_{2}+\ldots+a_{2 n} x_{n}=b_{2} \\
& a_{m 1} x_{1}+a_{m 2} x_{2}+\ldots+a_{m n} x_{n}=b_{m} \\
& x_{1}, x_{2}, \ldots, x_{n} \geq 0
\end{aligned}
$$

Pada program linear ini, $x_{1}, x_{2}, \ldots ., x_{n}$ mewakili keputusan variabel yang tidak diketahui; $c_{1}, c_{2}, \ldots ., c_{n}$ adalah biaya koefisien; $b_{1}, b_{2}, \ldots ., b_{n}$ adalah nilai disamping kanan; dan $a_{i j}, i=1$ sampai $m$ dan $j=1$ sampai $n$, dinamakan koefisien teknologi.

Pernyataan (1) dinamakan fungsi objektif; (2) dinamakan kendala; dan (3) adalah kendala tidak negatif. Beberapa penyelesaian memenuhi semua kendala, dinamakan feasible solution.

Pada perumusan ini, kendala ditulis dalam bentuk persamaan. Umumnya, kendala program linear mempunyai relasi $\geq$ atau $\leq$ tetapi selalu dapat diubah dalam persamaan dengan penjumlahan slack variabel. Fungsi objektif(1) juga dapat diekpresikan sebagai maksimum sebagai pengganti minimum.

Penulisan matematika diatas, dapat dirumuskan menjadi :

Minimumkan $\sum_{j=1}^{n} c_{j} x_{j}$

Dengan kendala

$$
\begin{array}{ll}
\sum_{j=1}^{n} a_{i j} x_{j}=b_{i}, & i=1,2, \ldots, m \\
x_{j} \geq 0, & j=1,2, \ldots, m
\end{array}
$$

\section{Integer Programming}

Salah satu asumsi tehnik Program Linear adalah divisibility atau fractionality. Dengan kata lain, setiap variabel model dapat terjadi pada semua nilai nonnegatif, 
suatu nilai solusi yang kontinu. Dalam situasi keputusan tertentu, asumsi ini tidak realistik dan tidak dapat diterima. Misalnya, suatu solusi memerlukan 2,29 kapal selam dalam suatu sistem pertahanan adalah tidak mempunyai makna praktis. Dalam kasus ini, 2 atau 3 kapal selam harus disediakan (bukan 2,29). Masih banyak masalah lain dalam bidang industri dan bisnis yang memerlukan nilai bulat untuk variabel modelnya.

Definisi : Program Integer adalah suatu program linear dengan tambahan persyaratan bahwa semua atau beberapa variabel bernilai bulat tidak negatif, tetapi tidak perlu bahwa parameter model juga bernilai bulat.

Ada banyak kasus dalam masalah Program Integer yang membatasi variabel model bernilai nol atau satu. Dalam kasus demikian, persoalan lintasan hanya memiliki dua pilihan yaitu masuk atau keluar dari jaringan. Jika variabel ini bernilai satu, persoalan masuk, dan jika variabel bernilai nol, persoalan keluar.

Dalam masalah program integer, jika persoalan mengharapkan semua variabel basis bernilai integer (bulat positif atau nol), dinamakan pure(all) integer programming. Jika persoalan hanya mengharapkan variabel-variabel tertentu bernilai integer, dinamakan mixed integer programming. Dan jika persoalan hanya mengharapkan nilai nol atau satu untuk variabelnya, dinamakan zero one integer programming.

Walaupun persoalan umum 0-1 linear programming dapat diselesaikan dengan algoritma cutting plane atau branch-and-bound, balas mengembangkan suatu algoritma enumerative yang efisien dan menarik untuk meyelesaikan persoalan ini. Sangat singkat sebagai dasar program integer nonlinear. Fungsi digunakan untuk menyamaratakan kesalahan metode untuk menyelesaikan persoalan all integer dan mixed-integer nonlinear programming.

Penyelesaian program integer seperti program linear, dengan rumus seperti dibawah ini :

$$
\begin{aligned}
& \text { Minimumkan } \sum_{i=1}^{m} \sum_{j=1}^{m} c_{i j} x_{i j} \\
& \text { Kendala } \sum_{j=1}^{m} x_{i j}-\sum_{k=1}^{m} x_{k i}=\left\{\begin{array}{lll}
1 & j i k a & i=1 \\
0 & j i k a & i \neq 1 \\
1 & j i k a & 1=m
\end{array} \text { atau } m\right. \\
& x_{i j} \geq 0 \quad i, j=1,2, \ldots, m
\end{aligned}
$$




\section{Knapsack}

Algoritma 0 - 1 Programming merupakan salah satu tipe masalah Knapsack dimana keadaan tertentu terjadi, masing-masing keadaan mempunyai sebuah nilai yang dihubungkan dengan besarannya. Secara nyata bahwa solusi optimal dari masalah knapsack akan menunjukkan kemungkinan yang terbaik.

Pada masalah ini akan terdorong untuk menyelesaikan suatu persoalan dalam menentukan lintasan terpendek pada suatu distribusi aliran. Pendekatan yang sederhana dapat dimasukkan ke dalam program komputer untuk memriksa semua harga $0-1$ yang mungkin, dipilih yang terbaik yang memenuhi kendala.

Contoh : Persoalan Knapsack

Seorang pendaki gunung ingin membawa semua peralatan yang ia perlukan dalam satu kantong (sack) saja, Misalkan ada sejumlah n peralatan yang diperlukan, tetapi ia tidak ingin berat seluruhnya melebihi $\mathrm{b} \mathrm{kg}$. Misalkan jenis peralatan ialah $x_{j}$ dan,

$$
X_{j}=\left\{\begin{array}{lll}
1 & \text { bila } & \text { alat } k e-j \text { ikut } \\
0 & \text { bila } & \text { alat } k e-j \text { tidak }-i k u t
\end{array}\right.
$$

Berdasarkan keterangan diatas, persoalan dapat dirumuskan sebagai berikut :

$\operatorname{Max} f=c_{1} X_{1}+c_{2} X_{2}+\ldots . .+c_{n} X_{n}$

Dengan kendala

$$
\begin{gathered}
a_{1} X_{1}+a_{2} X_{2}+\ldots .+a_{n} X_{n} \leq b \\
X_{1} X_{2}, \ldots \ldots \ldots \ldots X_{n}=0 \text { atau } 1
\end{gathered}
$$

Persoalan ini merupakan persoalan Knapsack sebagai persoalan nol satu (0-1). Definisi : $0-1$ atau biner, persoalan Knapsack yaitu masukkan dari $n$ item dan suatu knapsack, dengan

$$
\begin{aligned}
& P_{j}=\text { keuntungan dari item } j, \\
& w_{j}=\text { bobot dari item } j, \\
& c=\text { kapasitas dari knapsack. }
\end{aligned}
$$

Pilih subset dari item sebagai

Maksimumkan $\mathrm{z}=\sum_{j=1} p_{j} x_{j}$ 
$\begin{array}{ll}\text { Dengan kendala } & \sum_{j=1}^{n} w_{j} x_{j} \leq c, \\ & x_{j} 0 \text { atau } 1, j \varepsilon N\{1, \ldots . ., n\}\end{array}$

Dimana

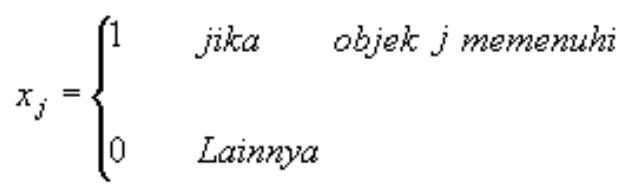

(Martello. S. et al, 1990)

\section{Dynamic Programming}

Dynamic Programming adalah teknik manajemen sain yang diaplikasikan kepada persoalan yang melibatkan keputusan berurutan yang slaing berkaitan. Program ini dikembangkan oleh Richard Bellman dan G. B Dantzing pada tahun 1940 - 1950. Sebagai sebuah konsep, Dynamic Programming lebih luwes dibanding program optimasi lainnya. Aplikasi Dynamic Programming lebih luwes dibanding program - program optimasi lainnya. Aplikasi Dynamic Programming sudah terbukti baik pada pengelolaan persediaan, jaringan, penjadwalan kerja utnuk karyawan, pengendalian produksi, perencanaan penjualan dan bidang lainnya.

Dynamic Programming adalah metode pemecahan masalah dengan cara menguraikan solusi menjadi sekumpulan langkah (step) atau tahapan (stage) sedemikian sehingga solusi dari persoalan dapat dipandang dari serangkaian keputusan yang saling berkaitan.

Pada penyelesaian persoalan dengan metode Dynamic Programming ini terdapat sejumlah berhingga pilihan yang mungkin, solusi pada setiap tahap dibangun dari hasil solusi tahap sebelumnya, kita menggunakan optimasi dan kendala untuk membatasi sejumlah pilihan yang harus dipertimbangkan pada suatu tahap.

\section{Konsep Dasar Dalam Dynamic Programming}

a. Dekomposisi

Persoalan Dynamic Programming dapat dipecah - pecah menjadi subpersoalan atau tahapan yang lebih kecil dan berurutan. Setiap tahap juga sebagai titik keputusan. Setiap keputusan yang dibuat pada suatu tahap akan mempengaruhi keputusan-keputusan pada tahap berikutnya. 
b. Status

Status adalah kondisi awal (Sn) dan kondisi akhir (Sn-1) pada setiap tahap tersebut keputusan dibuat (Dn). Status akhir pada setiap tahap tergantung kepada status awal dan keputusan yang dibuat pada tahap yang bersangkutan. Status akhir pada suatu tahap merupakan input bagi tahap berikutnya.

c. Variabel Keputusan dan Hasil

Keputusan yang dibuat pada setiap tahap (Dn) merupakan keputusan yang berorientasi kepada return yang diakibatkannya $(\mathrm{Rn} / \Delta n$, tingkat maksimal atau minimal.

d. Fungsi Transisi

Fungsi transisi menjelaskan secara pasti bagaimana tahap-tahap saling berhubungan. Fungsi ini berbentuk fungsi hubungan antar status pada setiap tahap yang berurutan. Fungsi transisi secara umum berbentuk: $\mathrm{Sn}-1=\mathrm{Sn}-$ Dn, dimana Sn-1 = status pada tahap n-1 atau status akhir pada tahap-n. Sn adalah status awal pada tahap-n

Komponen pada setiap tahap dapa digambarkan sebagai berikut:

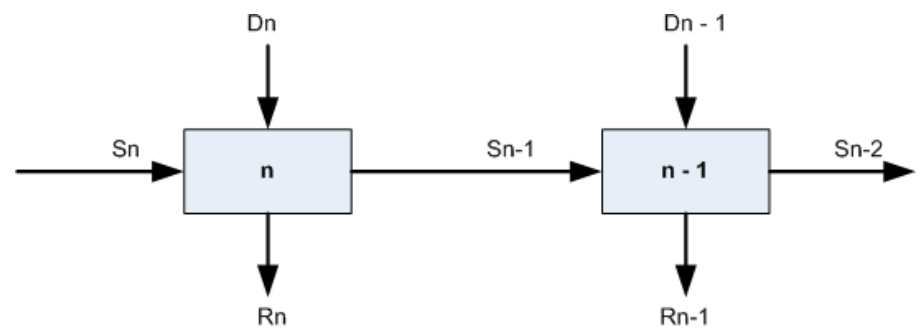

Gambar 2.7 Tahapan Fungsi Transisi

e. Optimasi Tahap

Optimasi tahap dalam Dynamic Programming adalah menemukan keputusan optimal pada setiap tahap dari berbagai kemungkinan nilai status inputnya.

Fungsi umum dari keputusan optimal adalah:

$\mathrm{Fn}(\mathrm{Sn}, \mathrm{Dn})=$ return pada tahap-n dari nilai status input Sn, dan keputusan Dn.

Fn* $(\mathrm{Sn})=$ return optimal pada tahap-n dari nilai input status $\mathrm{Sn}$.

f. Fungsi Rekursif

Fungsi rekursif biasanya digunakan berbagai program komputer, dimana nilai sebuah variabel pada fungsi itu merupakan nilai kumulatif dari nilai variael tersebut pada tahap sebelumnya. Pada Dynamic Programming, fungsi umu dituliskan sebaai: $\mathrm{fn}(\mathrm{Sn}, \mathrm{Dn})=\mathrm{Rn}+\mathrm{fn}-1 *(\mathrm{~S}-1, \mathrm{Dn}-1)$

Prosedur optimasi diawali dari tahap akhir menuju tahap awal (backward). 
Karakteristik program dinamis adalah:

a. Persoalan dapat dipisahkan menjadi beberapa tahap (stages), dimanasetiap tahap membutuhkan keputusan kebijakan yang standard dan saling berhubungan.

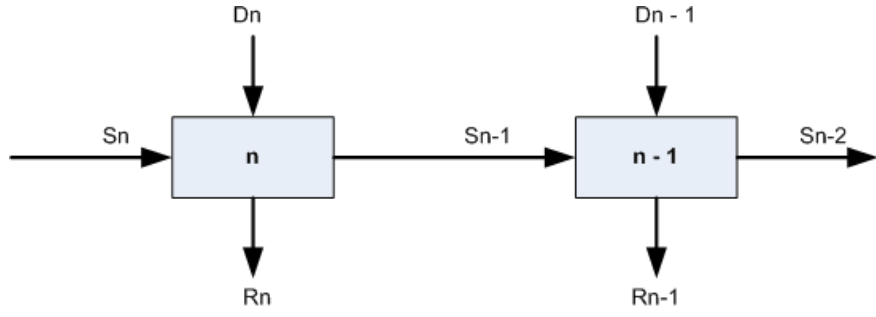

Gambar 2.8 Tahapan (stage) Standard

b. Setiap tahap memiliki sejumlah status (state). Secara umum, sekumpulan status ini merupakan berbagai kemungkinan yang timbul dari sistim persoalannya. Status ini memberikan informasi uang dibutuhkan setiap keputusan dan dampaknya pada tahap berikutnya. Jumlah status pada setiap tahap bisa definit atau infinit.

c. Setiap keputusan kebijakan yang dibuat pada suatu tahap, status pada tahap tersebut ditransformasi ke dalam status yang berkaitan pada tahap berikutnya. Hubungan antar status pada tahap yang berurutan bisa bersifat deterministic atau probabilistik.

Pada persoalan dengan n-tahap, ada dua input, yaitu : (1) state pada tahap-n (Sn) dan decision variabel $(\mathrm{Xn})$. Sedang outputnya adalah : (1) return atau akibat dari setiap Xn yang dipilih, fn(s,Xn) dan (2) status baru yang menjadi input pada tahap berikutnya (Sn-1). Hubungan antara Xn dan $\mathrm{fn}(\mathrm{s}, \mathrm{Xn})$ ditemukan oleh return function. Sedang hubungan antar status pada tahap tertentu ditentukan oleh transition function

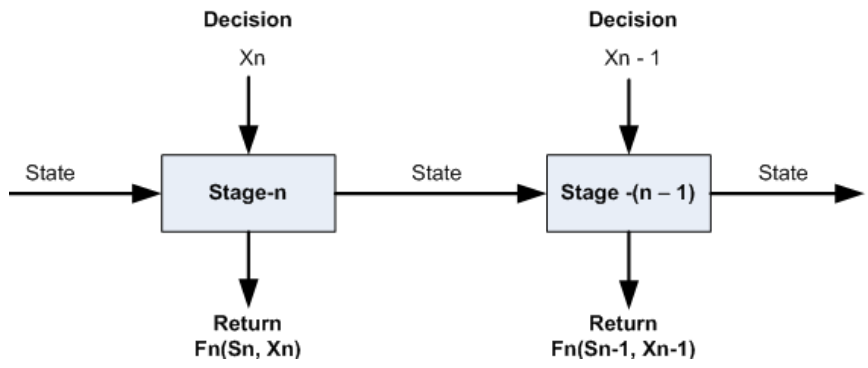

Gambar 2.9. Return dan Transition Function 
d. Solusi pada Dynamic Programming berprinsip kepada optimalitas yang dikembangkan oleh Bellman.

e. Keputusan pada tahap berikutnya bersifat independen terhadap keputusan sebelumnya. Untuk menyelesaikan persoalan Dynamic Programming, dimulai dari solusi awal pada suatu tahap dan secara berurutan menuju tahap berikutnya dengan proses yang terbalik (backward induction process).

f. Solusi optimal yang dihasilakn padasetiap tahap berprinsip kepada hubungan dalam bentuk fungsi rekursif (recursion relationship). Secara umum bentuk fungsi rekursif adalah:

$\mathrm{Fn} *(\mathrm{Sn})=\max / \min \{\mathrm{fn}(\mathrm{Sn}, \mathrm{Xn})\}$

Dimana $\mathrm{fn}^{*}(\mathrm{Sn})=$ hasil optimal dari keputusan pada tahap-n.

\section{Analisa Algoritma Dynamic Programming}

Dynamic Programming adalah metode pemecahan masalah dengan cara menguraikan solusi menjadi sekumpulan langkah (step) atau tahapan (stage) sedemikian sehingga solusi dari persoalan dapat dipandang dari serangkaian keputusan yang saling berkaitan.

Pada penyelesaian persoalan dengan Dynamic Programming terdapat sejumlah berhingga pilihan yang mungkin, solusi pada setiap tahap dibangun dari hasil solusi tahap sebelumnya, kita menggunakan persyaratan optimasi dan kendala untuk membatasi sejumlah pilihan yang harus dipertimbangkan pada suatu tahap.

Pada Dynamic Programming, rangkaian keputusan yang optimal dibuat dengan menggunakan Prinsip Optimalitas. Prinsip Optimalitas: jika solusi total optimal, maka bagian solusi sampai tahap ke-k juga optimal. Prinsip optimalitas berarti bahwa jika kita bekerja dari tahap $\mathrm{k}$ ke tahap $\mathrm{k}+1$, kita dapat menggunakan hasil optimal dari tahap $\mathrm{k}$ tanpa harus kembali ke tahap awal, ongkos pada tahap $\mathrm{k}+1=($ ongkos yang dihasilakn pada tahap $\mathrm{k}$ ) + (ongkos dari tahap k ke tahap $\mathrm{k}+1)$. Dengan prinsip optimalitas ini di jamin bahwa pengembalian keputusan pada suatu tahap adalah keputusan yang benar untuk tahap-tahap selanjutnya.

\section{Dua Pendekatan Algoritma Dynamic Programming}

Dua pendekatan yang digunakan dalam Dynamic Programming yaitu: maju (forward atau up-down) dan mundur (backward atau bottom up). Misalakan $\mathrm{x}_{1}$, $\mathrm{x}_{2}, \mathrm{x}_{3}, \ldots, \mathrm{x}_{\mathrm{n}}$ meyatakan peubah (variable) keputusan yang harus dibuat masingmasing untuk tahap $1,2, \ldots, n$. Maka:

1. Dynamic Programming maju. Dynamic programming bergerak mulai dari tahap 1 , terus maju ke tahap 2, 3, dan seterusnya sampai tahap $n$. runtunan peubah keputusan adalah $\mathrm{x}_{1}, \mathrm{x}_{2}, \mathrm{x}_{3}, \ldots, \mathrm{x}_{\mathrm{n}}$. 
2. Dynamic Programming mundur. Dynamic Programming bergerak mulai dari tahap $\mathrm{n}$, terus mundur ke tahap n-1, n-2, dan seterusnya sampai tahap 1 . runtunan peubah keputusan adalah $\mathrm{x}_{\mathrm{n}}, \mathrm{x}_{\mathrm{n}-1}, \mathrm{x}_{\mathrm{n}-2}, \ldots, \mathrm{x}_{1}$.

Langkah-langkah Pengembangan Algoritma Dynamic Programming

1. Karakteristik struktur solusi optimal.

2. Definisikan secara rekursif nilai solusi optimal.

3. Hituang nilai solusi optimal secara maju atau mundur.

4. konstruksi solusi optimal.

\section{Algoritma Dynamic Programming}

Algoritma Dynamic Programming adalah sebagai berikut :

Langkah 0 (inisialisasi):

Inisialisasi $s_{i}=0$ dan $d_{i}=m_{a i}$ untuk $i=1,2, \ldots ., n$

Langkah 1:

1. Isi $s_{a}$ dengan 1 (karena simpul a adalah simpul asal lintasan terpendek, jadi sudah pasti terpilih).

2. Isi $d_{a}$ dengan $\infty$ (tidak ada lintasan terpendek dari simpul a ke a) Langkah $2,3, \ldots, n-1$ :

1. Cari $j$ sedemikian sehingga $s_{j}=0$ dan $d_{j}=\min \left\{d_{1}, d_{2}, \ldots . ., d_{n}\right\}$

2. Isi $s_{j}$ dengan 1

3. Perbarui $d_{i}, \quad$ untuk $i=1,2,3, \ldots ., n$ dengan :

$$
d_{i}(\text { baru })=\min \left\{d_{i}(\text { lama }), d_{j}+m_{j i}\right\}
$$

\section{Shortest Path}

Andaikan diberikan sebuah graph $\mathrm{G}$ dalam tiap edge $(x, y)$ dihubungkan dengan verteks $a(x, y)$ mewakili panjang dari edge. Dalam beberapa hal, panjang sebenarnya mewakili biaya atau beberapa nilai lainnya. Panjang dari lintasan adalah menentukan panjang jumlah dari masing-masing edge yang terdiri dari lintasan. Untuk 2 verteks s dan $t$ dalam $\mathrm{G}$, ada beberapa lintasan dari s dan t. Masalah lintasan terpendek meliputi pencarian lintasan dari s ke tyang mempunyai lintasan terpendek dan biaya termurah. 
Pada persoalan ini akan terdorong untuk menyelesaikan suatu persoalan untuk menentukan lintasan terpendek dan biaya termurah dalam suatu jaringan dengan mengimplementasikannya ke dalam persoalan knapsack yang merupakan salah satu persoalan 0-1 programming.

\section{Analisis Knapsack}

Masalah knapsack ini dapat dirumuskan secara matematika dengan memberi nilai pada objek dari 1 sampai $n$ dan memperkenalkan suatu vektor dari variabel biner $x_{j}(j=1, \ldots, n)$ yang memiliki arti sebagai berikut :

$$
x_{j}= \begin{cases}1 & \text { Jika objek } j \text { memenuhi } \\ 0 & \text { Lainnya }\end{cases}
$$

Jika merupakan ukuran dari kelayakan yang diberikan oleh objek adalah besarannya dan adalah besaran dari knapsack, masalahnya akan terpilih, diantara semua vektor biner yang akan memenuhi kendala

$$
\begin{aligned}
& \sum_{j=1}^{n} w_{j} x_{j} \leq c, \\
& x_{j}=0 \text { atau } 1 \quad j \in N\{1, \ldots, n\}
\end{aligned}
$$

Dimana salah satu fungsi objektif di maksimalkan

$$
\sum_{j=1}^{n} p_{j} x_{j}
$$

Contoh 3.1 Persoalan lintasan terpendek diimplementasikan ke dalam knapsack.

Suatu aliran adalah sebuah perjalanan objek dari suatu tempat ke tempat lain dalam suatu jaringan kerja, seperti penyaluran air bersih pada saluran pipa. Banyak masalah penting yang perlu diperhatikan pada aliran dalam jaringan kerja, seperti menimimumkan jumlah materi yang akan disalurkan dari suatu pipa ke pipa lain, dan menentukan biaya penyaluran yang paling minimum untuk mengirimkan sejumlah objek dari sumber persediaan ke tujuan, atau mencari jalan terpendek pada pengiriman objek dalam suatu sistem. Berikut ini adalah representasi graph pada penyaluran air bersih. 


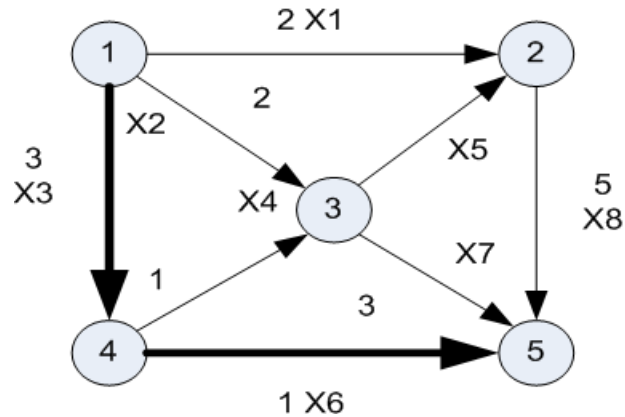

Ada bermacam - macam pendekatan yang dapat digunakan untuk menyelesaikan persoalan ini. Beberapa diantaranya adalah :

\section{Cara Enumerasi}

Persoalan ini adalah persoalan program integer, yang dapat dimasukkan ke dalam persoalan knapsack.

Minimumkan $\sum_{i=1}^{m} \sum_{j=1}^{m} c_{i j} x_{i j}$

$$
\begin{aligned}
\text { Dengan kendala } \sum_{j=1}^{m} x_{i j}-\sum_{k=1}^{m} & =\left\{\begin{array}{lrl}
1 & & i=1 \\
0 & \text { jika } i \neq 1 \\
-1 & \text { jika } i=m
\end{array} \text { atau } m\right. \\
x_{i j} & =0 \text { atau } 1 \\
x_{i j} & \geq 0 \quad i, j=1,2, \ldots, m
\end{aligned}
$$

Karena persoalan knapsack untuk mencari persoalan 0 dan 1, dan kendala diatas atau 1, maka persoalan ini dinamakan persoalan knapsack.

Maka :

$$
\begin{aligned}
& \text { Minimumkan } \sum_{i=1}^{5} \sum_{j=1}^{5} c_{i j} x_{i j} \\
& =\sum_{i=1}^{5}\left(c_{i 1} x_{i 1}+c_{i 2} x_{i 2}+c_{i 3} x_{i 3}+c_{i 4} x_{i 4}+c_{i 5} x_{i 5}\right) \\
& =\sum_{i=1}^{5} c_{i 1} x_{i 1}+\sum_{i=1}^{5} c_{i 2} x_{i 2}+\sum_{i=1}^{5} c_{i 3} x_{i 3}+\sum_{i=1}^{5} c_{i 4} x_{i 4}+\sum_{i=1}^{5} c_{i 5} x_{i 5}
\end{aligned}
$$




$$
\begin{aligned}
& c_{11} x_{11}+c_{21} x_{21}+c_{31} x_{31}+c_{41} x_{41}+c_{51} x_{51}+ \\
& c_{12} x_{12}+c_{22} x_{22}+c_{32} x_{32}+c_{42} x_{42}+c_{52} x_{52}+ \\
= & c_{13} x_{13}+c_{23} x_{23}+c_{33} x_{33}+c_{43} x_{43}+c_{53} x_{53}+ \\
& c_{14} x_{14}+c_{24} x_{24}+c_{34} x_{34}+c_{44} x_{44}+c_{54} x_{54}+ \\
& c_{15} x_{15}+c_{25} x_{25}+c_{35} x_{35}+c_{45} x_{45}+c_{55} x_{55}
\end{aligned}
$$

Dari hasil subsitusi diatas, maka diperoleh :

Minimumkan $Z=c_{12} x_{12}+c_{32} x_{32}+c_{13} x_{13}+c_{43} x_{43}+c_{14} x_{14}+c_{25} x_{25}+c_{35} x_{35}+c_{45} x_{45}$

Dengan kendala :

$$
\begin{array}{rlrl}
\sum_{j=1}^{5} x_{i j}-\sum_{k=1}^{5}=\left\{\begin{array}{lll}
1 & \text { jika } & \\
0 & \text { jika } & i=1 \\
-1 & \text { itau } m
\end{array}\right. \\
x_{i j}=0 \text { atau } 1 & \\
x_{i j} \geq 0 & i . j=1,2, \ldots, m
\end{array}
$$

Titik $1\left(x_{11}+x_{12}+x_{13}+x_{14}+x_{15}\right)-\left(x_{11}+x_{21}+x_{31}+x_{41}+x_{51}\right)=1$

Titik $2\left(x_{21}+x_{22}+x_{23}+x_{24}+x_{25}\right)-\left(x_{12}+x_{22}+x_{32}+x_{42}+x_{52}\right)=0$

Titik $3\left(x_{31}+x_{32}+x_{33}+x_{34}+x_{35}\right)-\left(x_{13}+x_{23}+x_{33}+x_{43}+x_{53}\right)=0$

Titik $4\left(x_{41}+x_{42}+x_{43}+x_{44}+x_{45}\right)-\left(x_{14}+x_{24}+x_{34}+x_{44}+x_{54}\right)=0$

Titik $5\left(x_{51}+x_{52}+x_{53}+x_{54}+x_{55}\right)-\left(x_{15}+x_{25}+x_{35}+x_{45}+x_{55}\right)=-1$

\section{Dengan kendala}

Titik $1 \quad X_{12}+X_{13}+X_{14}=1$

Titik $2 X_{25}-X_{12}-X_{32}=0$

Titik $3 \quad X_{32}+X_{35}-X_{13}-X_{43}=0$

Titik $4 X_{43}+X_{45}-X_{14}=0$

Titik $5-X_{25}-X_{35}-X_{45}=-1$

Setelah disubsitusikan maka :

$\operatorname{Min} \mathrm{Z}=C_{12} X_{12}+C_{13} X_{13}+C_{14} X_{14}+C_{25} X_{25}+C_{32} X_{32}+C_{35} X_{35}+C_{43} X_{43}+C_{45} X_{45}$ 
Dengan kendala :

Titik $1 X_{12}+X_{13}+X_{14}=1$

Titik $2 X_{25}-X_{12}-X_{32}=0$

Titik $3 \quad X_{32}+X_{35}-X_{13}-X_{43}=0$

Titik $4 \quad X_{43}+X_{45}-X_{14}=0$

Titik $5-X_{25}-X_{35}-X_{45}=-1$

Lalu masukkan biaya masing-masing

$\operatorname{Min} Z=2 X_{1}+2 X_{2}+3 X_{3}+X_{4}+4 X_{5}+X_{6}+3 X_{7}+5 X_{8}$

Dengan kendala :

Titik $1 \quad X_{1}+X_{2}+X_{3}=1$

Titik $2 X_{8}-X_{1}-X_{5}=0$

Titik $3 \quad X_{5}+X_{7}-X_{2}-X_{4}=0$

Titik $4 \quad X_{4}+X_{6}-X_{3}=0$

Titik $5 \quad X_{8}-X_{7}-X_{6}=-1$

$X_{1}, X_{2}, X_{3}, X_{4}, X_{5}, X_{6}, X_{7}, X_{8}=0$ atau 1

Model ini dapat diselesaikan dengan metode Branch and Bound dengan cara menambahkan delapan kendala berikut untuk mengantikan kendala $X_{1}, X_{2}, X_{3}, X_{4}, X_{5}, X_{6}, X_{7}, X_{8}=0$ atau 1.

Kedelapan kendala ini adalah :

$X_{1} \leq 1, X_{2} \leq 1, X_{3} \leq 1, X_{4} \leq 1, X_{5} \leq 1, X_{6} \leq 1, X_{7} \leq 1, X_{8} \leq 1$

Cara lain untuk menyelesaikan masalah ini secara efisien adalah dengan complete enumeration. Dengan cara ini solusi yang tak memenuhi diabaikan dan solusi yang memenuhi dievaluasi untuk dipilih yang terbaik.

\section{Analisis Dynamic Programming}

Dynamic Programming merupakan metode pemecahan masalah dengan cara menguraikan solusi menjadi sekumpulan langkah (step) atau tahapan (stage) sedemikian sehingga solusi dari persoalan dapat dipandang dari serangkaian keputusan yang saling berkaitan.

Pada dynamic programming, rangkaian keputusan yang optimal dibuat dengan menggunakan Prinsip Optimalisasi. Prinsip Optimalisasi: jika solusi optimal, maka bagian solusi pada tahap ke- $k$ juga optimal. Prinsip Optimalisasi berarti bahwa jika 
kita bekerja dari tahap $k$ ke tahap $k+1$, kita dapat menggunakan hasil optimal dari tahap $k$ tanpa harus kembali ke tahap awal. Ongkos pada tahap $k+1=$ (ongkos yang dihasilkan pada tahap $k)+($ ongkos dari tahap $k$ ke tahap $k+1)$. Dengan prinsip optimalisasi ini dijamin bahwa pengambilan keputusan yang benar untuk tahap-tahap selanjutnya.

Algoritma Dynamic Programming adalah sebagai berikut :

Langkah 0 (inisialisasi) :

$$
\text { Inisialisasi } s_{i}=0 \text { dan } d_{i}=m_{a i} \text { untuk }
$$

Langkah 1:

1. isi $s_{a}$ dengan 1 (Karena simpul a adalah simpul asal jalur terpendek, jadi sudah pasti terpilih).

2. isi $d_{a}$ dengan 0 (tidak ada lintasan terpendek dari simpul a ke a). Langkah $2,3, \ldots, \mathrm{n}-1$ :

1. Cari $j$ sedemikian sehingga $s_{j}=0$ dan $d_{j}=\min \left\{d_{1}, d_{2}, \ldots, d_{n}\right\}$

2. Isi dengan 1

3. perbaharui $d_{i}$ untuk $i=1,2,3, \ldots, n$ dengan $d_{i}$ (baru)

$$
=\min \left\{d_{i}(\text { lama }), d_{j}+m_{j i}\right\}
$$

Algoritma dynamic programming bekerja dengan cara menyimpan setiap simpul $\mathrm{v}$, dengan $\mathrm{d}[\mathrm{v}]$ menyatakan lintasan terpendek yang telah ditemukan antara $\mathrm{s}$ dan v. Pada awalnya, nilai ini adalah 0 untuk sumber simpul s $(d[s]=0)$, dan ketidakterbatasan untuk semua simpul lain, yang menyatakan fakta bahwa kita tidak mengetahui lintasan manapun yang mengacu ke arah simpul itu $(\mathrm{d}[\mathrm{v}]=$ untuk tiaptiap v didalam V, kecuali s). Ketika algoritma berhenti, d[v] akan menyatakan nilai lintasan yang paling pendek dari s sampai v atau bernilai tak berhingga, jika lintasan tersebut tidak ada.

Operasi dasar dari algoritma dynamic programming adalah relasi sisi jika ada suatu sisi dari $\mathrm{u}$ ke $\mathrm{v}$, kemudian diketahui lintasan yang paling pendek dari $\mathrm{s} \mathrm{ke} \mathrm{u}$ $(\mathrm{d}[\mathrm{u}])$ dapat diperluas menjadi lintasan dari s ke v dengan menambahkan sisi $(\mathrm{u}, \mathrm{v})$ pada bagian akhir. Lintasan akan mempunyai panjang $\mathrm{d}[\mathrm{u}]+\mathrm{w}(\mathrm{u}, \mathrm{v})$. jika nilai ini adalah kurang dari $\mathrm{d}[\mathrm{v}]$ yang sekarang, kita dapat menggantikan nila $\mathrm{d}[\mathrm{v}]$ yang sekarang dengan nilai yang baru itu. Relaksasi sisi diterapkan sampai semua nilainilai d[v] mengembalikan nilai lintasan yang paling pendek dari s ke v. Algoritma ini 
diorganisir sedemikian sehingga masing-masing sisi $(\mathrm{u}, \mathrm{v})$ direlaksasi hanya sekali, ketika d[u] telah mencapai nilai akhirnya.

Ide relaksasi ini datang dari suatu analogi antara perkiraan lintasan yang paling pendek dan panjang suatu pegas seperti bentuk sekerup yang bukan dirancang untuk tekanan. Pada awalnya, nilai lintasan yang paling pendek adalah suatu optimisasi yang dianalogikan dengan pegas. Ketika lintasan lebih pendek ditemukan, nilai yang telah diperkirakan diturunkan, dan pegas diperlonggar.

Algoritma memelihara dua himpunan simpul S dan Q, himpunan $\mathrm{S}$ berisi semua simpul yang telah kita ketahui bahwa nilai $\mathrm{d}[\mathrm{v}]$ adalah sudah merupakan nilai terpendek dan himpunan Q berisi semua simpul lainnya. Pada awalnya himpunan kosong, dan pada setiap langkah satu simpul dipindahkan dari Q ke S. Simpul ini dipilih sebagai simpul dengan nilai d[u] paling rendah. Ketika suatu simpul u dipindahkan ke S, algoritma ini merelaksasi setiap sisi (u,v).

Contoh : Sebuah rute dari St. Louis ke San Francisco melalui beberapa kota antara seperti yang terlihat pada gambar jaringan berikut:

Angka pada setiap garis penghubung merupakan jarak. Dari gambar rute tersebut, maka persoalan ini dapat dibagi menjadi empat tahap (nomor tahap dimulai dari kota tujuan berurutan ke kota asal).

\section{Tahap-1:}

\begin{tabular}{|c|c|c|c|}
\hline $\begin{array}{ll} & \text { X1 } \\
\text { S1 } & \\
\end{array}$ & $\mathbf{f 1}(\mathbf{S} 1, \mathbf{X} 1)=\mathbf{C}(\mathbf{S} 1, \mathrm{X} 1)$ & f1 * (S1) & $\mathbf{X} 1$ * \\
\hline & 10 & & \\
\hline 8 & 6 & 6 & 8 \\
\hline 9 & 8 & 8 & 9 \\
\hline
\end{tabular}

\section{Tahap-2 :}

\begin{tabular}{|c|c|c|c|c|}
\hline $\begin{array}{ll} & \mathrm{X} 2 \\
\mathrm{~S} 2 & \end{array}$ & $\begin{array}{r}\mathrm{f} 2(\mathrm{~S} 2, \mathrm{X} 2 \\
+\mathrm{f}\end{array}$ & $\begin{array}{l}\mathrm{C}(\mathrm{S} 2, \mathrm{X} 2) \\
\mathrm{s} 1)\end{array}$ & f2 * (S2) & X2 * \\
\hline & 8 & 9 & & \\
\hline 5 & $3+6=9$ & $7+8=15$ & 9 & 8 \\
\hline 6 & $2+6=8$ & $5+8=13$ & 8 & 8 \\
\hline 7 & $7+6=13$ & $3+8=11$ & 11 & 9 \\
\hline
\end{tabular}


Tahap-3:

\begin{tabular}{|c|c|c|c|c|c|}
\hline \multirow{2}{*}{ S3 } & $\mathbf{X 3}$ & \multicolumn{2}{|c|}{$\mathbf{f 3}(\mathbf{S 3}, \mathbf{X 3})=\mathbf{C}(\mathbf{S 3}, \mathbf{X 3})+\mathbf{f 2} *(\mathbf{S} 2)$} & \multirow{2}{*}{$\mathbf{f}$ * (S3) } & \multirow{2}{*}{$\mathbf{X 3}$ * } \\
\hline & $\mathbf{5}$ & $\mathbf{6}$ & $\mathbf{7}$ & & \\
\hline $\mathbf{2}$ & $6+9=15$ & $7+8=15$ & $4+11=15$ & 15 & $\mathbf{5}$ or 7 \\
\hline $\mathbf{3}$ & $2+9=11$ & $5+8=13$ & $3+11=14$ & 11 & $\mathbf{5}$ \\
\hline $\mathbf{4}$ & $5+9=14$ & $3+8=11$ & $4+11=15$ & 14 & $\mathbf{5}$ \\
\hline
\end{tabular}

\section{Tahap-4:}

\begin{tabular}{|c|c|c|c|c|c|}
\hline \multirow{2}{*}{$\begin{array}{ll} & \text { X4 } \\
\text { S4 } & \\
\end{array}$} & \multicolumn{3}{|c|}{$\mathrm{f} 4(\mathrm{~S} 4, \mathrm{X} 4)=\mathrm{C}(\mathrm{S} 4, \mathrm{X} 4)+\mathrm{f3} *(\mathrm{~S} 3)$} & \multirow{2}{*}{ f4 * (S4) } & \multirow{2}{*}{$\mathrm{X} 4$ * } \\
\hline & 2 & 3 & 4 & & \\
\hline 1 & $3+15=18$ & $5+11=16$ & $2+14=16$ & 16 & 3 or 4 \\
\hline
\end{tabular}

Pembacaan tabel-tabel ini untuk menentukan tingkat optimal adalah dari tahap- $4 \rightarrow$ tahap-3 $\rightarrow$ tahap-2 $\rightarrow$ tahap- 1 .

Rute optimal dengan jarak minimal adalah :

$1 \rightarrow 3 \rightarrow 5 \rightarrow 8 \rightarrow 10$, dengan total jarak $=5+2+3+6=16$, atau

$1 \rightarrow 4 \rightarrow 5 \rightarrow 8 \rightarrow 10$, dengan total jarak $=2+5+3+6=16$.

\section{KESIMPULAN}

Dalam menyelesaikan suatu persoalan shortest path dengan Knapsack untuk menentukan lintasan tependek dan biaya termurah dari sumber $s$ sampai ke tujuan $t$ pada suatu lintasan, dapat diselesaikan dengan metode mundur yang merupakan salah satu persoalan dari masalah knapsack. Persoalan ini juga merupakan persoalan 0-1 dynamic programming dimana solusi optimal akan menunjukkan kemungkinan pilihan yag terbaik.

\section{PUSTAKA}

1. Navneet Bhushan, "Strategic Decision Making: Applying The Analytic Hierarchy Process “, Springer

2. Peter Kall, "Stochastic Programming ", John Wiley \& Son

3. Richard Bellman, "Dynamic Programming ", Princeton University Press.

4. Rush D Robinett III, “Applied Dynamic Programming for Optimization of Dynamical Systems “, Siam 